\title{
EDUCATIONAL CONTEXT OF TIME FROM THE PERSPECTIVE OF ADULT DEVELOPMENT
}

\author{
JERZY SEMKÓW
}

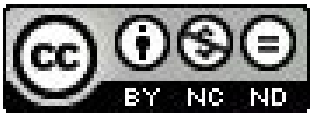

\author{
Faculty of Pedagogy, Janusz Korczak Pedagogical University in Warsaw, \\ Katowice - Department, Katowicka Str 27, Katowice \\ E-mail address: jerzysemkow@gmail.com
}

\begin{abstract}
The basic assumption is that time, which regulates our existence in the world, is the special medium and that there are "costs (lost opportunities) associated with not investing time wisely" (Zimbardo, \& Boyd, 2009, p. 19). The diverse attitudes of certain individuals towards time may be viewed from various perspectives. The author reflects on the time phenomenon from the perspective of learning adults, with regard to three life periods in the process identified in andragogy as maturing to adulthood. In early adulthood time is especially significant as people assume the role of the ones responsible for their professional development and their families. In the second stage - middle adulthood - due to varying evaluations of their achievements, time is treated either as a friend or as an enemy. In this situation undertaking learning activity becomes a springboard, some kind of antidote to the emerging life problems. It may also bring about fundamental disturbances to the psycho-social balance of an adult person, such as change of his living environment. The value of time as a non-renewable good increases significantly the in late adulthood, after crossing the threshold of 60 . This refers particularly to people who consider old age as an important stage of life. Thus, temporal perspective in each stage of adulthood varies, especially when learning is a regular part of life activities of an adult person.
\end{abstract}

Key words: educational context of time, early adulthood, middle adulthood, late adulthood, development of adults

\section{THE MEANING OF TIME IN HUMAN EXISTENCE}

Time, as the intangible phenomenon shaping the attitude of humans towards the surrounding reality, may on one hand serve as a special good, yet on the other, it may be treated as a curse. We assume that time - as the specific element of our existence in the world, that sets the limits of human life in the conditions of earthly reality - is this particular medium with which "there are costs (lost opportunities) associated", if it is not invested wisely (Zimbardo, \& Boyd, 2009, p. 19). For this reason, objectively speaking, its value cannot be 
questioned. Fortunately, we also have our subjective perspective from which we view time and thanks to which we evaluate it so differently. However, the significance of time, revealed in the way our perception of it influences our thinking and actions, seems to be decisive. For some people time - measured with years, months, weeks or even days - is some sort of a pressure, specific psychological stress acumulation of which forces them to fulfill successive tasks. Others may treat time as something that separates one event from another, one important life situation from another. There are also those who realize the importance of time passing by during events or meetings which do not enrich their previous experience nor do they improve their knowledge.

Let us consider the first approach towards time which is perceived as the most valuable element of our specifically understood good. Time pressure may be a positive factor when the awareness of time passing by becomes the stimulator for fulfilling our tasks in a reliable manner. It influences us negatively when the quality of the task we are to complete is lowered by the accompanying rush. Haste itself does not have to always bring poor results, yet the awareness of possible consequences of performing the work in a subjectively shorter time usually hinders us from proper performance. This phenomenon occurs often in academic works and even more frequently in the process of acquiring knowledge by learning adults. In this context, for example, an oral exam is a specific test for internalizing knowledge and understanding it in the time adequate to one's abilities.

Let us look at another way of perceiving time - as a space that separates one important event from another. For people who are immersed in the traditional worldview marked with religiosity, these important events are usually holidays (Christmas, Easter) or family anniversaries that emphasize trust in durability and sacredness of relations. A similar mechanism may occur in case of learning adults for whom time separating e.g. examination periods or exams - is an important or even defining element of their sense of satisfaction or even happiness. If all tasks scheduled for the given period are accomplished successfully, the final exams become the long anticipated fruit of hard work.

Situations when we experience the meaning of time through a loss require a separate discussion. The loss is accompanied by the feeling that hours, even days are spent on doing something that does not bring anything new into our previous psycho-intellectual resources. The subjective sense of time lost, which may accompany us during a social or academic meeting, is often successfully neutralized by the value we assign to the contact with people who for many different reasons are close to us. This is then when we also, on one hand, try to justify our unfortunate choices but on the other we find values where we have not seen them before. The more our present task seems detached from our supreme goal and from what we cherish the most, the more severe is our sense of time wasted. For example, for someone who invested in his scientific career, washing dishes, cleaning the house or gardening may seem a waste of time. However, when one realizes the usefulness of such activities in themselves, 
or even more - their usefulness from the perspective of a human body that requires physical exercise - such awareness sheds a completely different light on the whole situation. When rationally fulfilled, the rule of physical activity as an indispensable component of our psycho-intellectual wellbeing, fosters creative thinking of an individual. Thus, obeying this rule may contribute to one's progress e.g. in terms of career.

Here we come to the role of our subconscious supported by thinking that uses previously obtained knowledge. It is our subconscious that allows us to acknowledge that time we are to spend on physical exercises may have the value comparable to the time we reserve for intellectual work. Moreover, from the point of view of intellectual exercise, physical effort becomes particularly meaningful as the factor necessary for ensuring the quality of the first one.

Such different individual approaches to time could be complemented by more references to this phenomenon. One of them is "control over time" which - according to Zimbardo - may be achieved through using our "capacity for psychological change" (Zimbardo, \& Boyd, 2009, p. 49).

Psychological research, especially those by Philip Zimbardo and John Boyd, allowed us to identify six perspectives from which we view time: two past, two present and two future (Zimbardo, \& Boyd, 2009, p. 51). Without further characteristics thereof, it is worth noticing that these dimensions of viewing time from the past, present and future perspectives do not exhaust their types and configurations. One of them, called the "holistic presence", is worth presentation, especially as we participate in the process of advanced diffusion of cultural patterns (including the influence of African, and Middle and the Far Eastern culture on the Western world). It is this type of time perception that assumes the development of the ability "to live the moment", that is to concentrate fully on the present moment and to include past and future as an expanded state of focus on the present (Zimbardo, \& Boyd, 2009, p. 51). This way of viewing time and this attitude towards its potential finds many followers as it allows to gain control over the destructive influence of everyday life lived with the minimum participation of our consciousness (see: Chopra, 1995). However, it requires a higher state of consciousness and it can be achieved as a result of regular meditation practices that are the core of zen philosophy. It seems that in our condition it is also possible, or even necessary, to work on improving our consciousness towards recognizing its controlling role over what we do and how we live (Chopra, 1995, p. 57-61). So this way of viewing time, which is offered by the "holistic presence" frees us from the negative consequences: hedonic attitudes on one hand and fatalism on the other. Thus, it allows us to better find the sense of our life plans and actions.

Let us look at the time phenomenon from the perspective of learning adults, especially adults in their late adulthood. Identifying three known stages of adulthood or - according to Malcolm S. Knowles - developmental stages of adulthood, we can talk about a time aspect specific for early adulthood (20/25 - 35/40), a time aspect in middle adulthood (35/40 - 60/65) and time aspect 
characteristic for late adulthood (60/65 and above) (see: Knowles, Holton III, \& Swanson, 2009). As both early and middle adulthood are stages in human life that determine the period of late adulthood, I will characterize them briefly pointing out to their educational aspect.

\section{EARLY (YOUNG) ADULTHOOD}

Early adulthood can be characterized by close to optimal capacity to absorb knowledge and then apply it. This usually results in intensive learning and studying until at least 30 years of age. This is the "time of using ability of systemic and conscious problem-solving, combined with creative thinking" (Turner, \& Helms, 1999, p. 402). Entering early adulthood is at the same time the beginning of new situations which enable us to get to know ourselves and others. This, in turn, fosters the development of a more stabile sense of our identity. In this way young adults participate in the process of multidimensional development of all areas of their personality and allocating themselves within the mechanism of social functioning (Turner, \& Helms, 1999, p. 406). Learning helps them to choose their own course in life, with such important moments as: entering into an intimate relationship, marriage and having children. At this stage of life time plays a very special role, when we consider how intensively it is used by all those who desire to enter their adulthood in a responsible and effective manner. Of course, we cannot forget about the differences in "experiencing various aspects of adult life by young individuals" (Bee, 2004, p. 466). It is connected with the costs borne by young adults when they change the order of accepting and adapting to certain roles, e.g. having a child in the teenage years, like early marriage, usually results in negative consequences (Bee, 2004, p. 466). Considering some "normative order" in choosing social roles, sanctified by years of experience, seems to be the particular indicator of responsible adulthood. Here we should refer to the category of "social time" which "predetermines all social activities regardless of the community's ability to conceptualize this phenomenon (...) It also determines the methods of evaluation and coordination of activities undertaken by the members of this community towards one another (...) and to some extent, it also sets the limits of individual experience of time (e.g. through socially accepted forms of narration, socialization etc.) as well as possible strategies of dealing with this experience" (Jaśtal, 2015, p. 73). So this normative order of roles accepted by young adults is legitimised by social time.

No doubt, adulthood understood in such a way is supported by possibly advanced orientation in the meanders of adult life and the main source of it is the knowledge obtained through learning. In this context time seems to be a strong ally in this life stage, however in too many cases administration and use of time are still far from ideal. Where the hedonist lifestyle is continued and the importance of fun dominates in the world of a young adult, the agony 
may occur - of the whole period of maturing to social roles that constitute the model of a responsible man. Here we come to a very up-to-date problem of degradation of the learning, studying and self-development ethos which is pursued by some people in their early adulthood. In this case there is a danger of being convinced that we have enough time (common saying - "I have my whole life before $\mathrm{me}^{\prime \prime}$ ) and that wasting it does not yield any consequences, as the loss incurred may be compensated for later. But "nothing will allow us to regain time misspent" (Zimbardo, \& Boyd, 2009, p. 17).

Thus, it seems that in early adulthood we can talk about two attitudes towards time. On one hand there is the majority of people who are aware of the value of time as their specific asset, that should possibly be well invested; on the opposite pole are all those who do not view time as a particular good. Thus, they do not reflect on how they spend it. Generally speaking, however due to the variety of roles young adults are forced to play - time "goes fast" uncontrollably and the sense of insufficiency thereof becomes the more severe, the more complex become our tasks and duties associated with certain roles.

\section{LEARNING IN MIDDLE ADULTHOOD}

In this perspective, what are the attitudes towards time among people who have reached the second stage of adulthood - its more mature form? Middle adulthood - with consideration given to all possible individual differences - has some characteristics identified by the researchers as specific for this life stage. The difficulty in determining their character is connected with two contrary interpretations of the nature of middle age. Some view it as the time of crisis resulting from the negative self-evaluation, a period of depression marked with the feeling of unhappiness (Turner, \& Helms, 1999, p. 480). For many others, for whom - like in the title of the famous book - "Life begins at forty", time becomes an ally in their development. Therefore, from this point of view it is emphasized that middle age is the time of stabilizing one's identity through the improved self-knowledge, accepting one's ego along with the diversity of the surrounding world.

Some psychological research indicates that the beginning of the mature adulthood, that is the 40's brings about the so called "mid-life crisis" (Oles, 2000, p. 133-145). According to Daniel J. Levinson it results from the confrontation of an adult person with the range of responsibilities assigned to the middle age. Additionally, there is the "realization of one's own mortality, recognizing new physical limitations and increased risk of behaviour as well as big changes in most of the social roles" (Bee, 2004, p. 491). It is easy to notice that time passing by, leading to the awareness of, among others, the fact of biological ageing, may become a destructive factor that undermines faith in one's own abilities and thus, generates this crisis. Taking up some form of education often becomes a specific remedy for adults who entered their mature age. It allows them 
to break the routine of everyday professional or family responsibilities. Education or learning helps adult individuals and becomes a lifebuoy, saving from psychosocial downfall. Conscious learning in this period of life also serves as the factor complementing gaps and shortages of middle adulthood; individuals have the chance to strengthen and deepen the value of their life maturity.

According to the research by Guy Avanzin, as well as my partial studies ${ }^{2}$, education and learning during middle adulthood generally foster more effective accomplishing of personal and professional goals. The feeling of making a better use of one's time, that accompanies this situation, creates some sort of comfort. This, in turn, results in adding sense to an adult's existence. One can wonder, whether frequent cases when education affects adult individual's psychosocial balance and forces him to introduce many significant changes in his hitherto life, has value for development and maturing into adulthood? (Avanzini, 1993, p. 45-49). I think that events taking place due to one's education like leaving one's environment or family may be important factors in constructing a more mature personality. In this sense these, sometimes surprising, learning outcomes may be considered as very significant in the process of ongoing maturing into full adulthood.

It is different when participation in the education process leads to such deep changes in one's psyche that this person gives up the model of settling in life and rejects the established ways of socio-affective or socio-professional integration. Does it mean the rejection of the adulthood itself, as stated by G. Avanzini? If such general transformation entails the individual's deep belief that his new self is the real, right dimension of his personality - then it is hard not to notice that this is an important stage of maturing: not to postulated and, thus, falsified adulthood, but to the real one. By paradox, time also gains new perspective and therefore proper investing thereof becomes particularly valuable.

To summarize, we can say that the middle stage of life of learning adults either establishes them in their hitherto existential reality, or contributes to building a new identity and the shape and structure of it lead adults to a completely different life path. In this period individuals usually determine themselves "finally" and choose a relatively steady path for the next periods in their existence. This does not exclude the possibility to change one's life in the last stage of adulthood which brings human beings to the final, that is death.

2 In 2008-2010 I conducted a survey among external students of University of Wrocław, on evaluation of studies from the perspective of their own personal history and life satisfaction. Among the 115 respondents at the age over 40, more than half admitted that studies help them to meet new goals and to break the routine which had slowly become an important barrier to their development. Very few respondents viewed studying as the "necessary evil" because it complicated their vocational and family life. Another type of obstacle was the negative attitude or hostility of institutions' managers towards those subordinates who had taken up their education (some teachers were hiding the fact they were studying before their school Avanzininagers). 


\section{LATE ADULTHOOD FROM THE PERSPECTIVE OF TIME PASSING BY; THE VALUE OF TIME IN OLD AGE}

The value of time as the non-renewable and thus, volatile good increases evidently in the late adulthood. And while after their 60's more and more people live 20,30 or even 40 more years, the awareness of the fact that this is the last stage of life's pilgrimage strengthens our conviction that the end is inevitable. Despite that, this period creates potential "opportunities of great happiness, satisfaction and fulfillment" (Turner, \& Helms, 1999, p. 526). The negative image of the elderly is mostly due to the process of gradual rejection of still functioning in society .In the light of recent research on the ageing phenomenon, we can conclude that the nature of the last stage of life depends on individual viewing and individual attitude towards old age. Some see it as a chance for development and for life with dignity; others treat it as a necessary evil, give up and fulfill the black scenario of their last years of existence. Does it mean the negative patterns of old age must inevitably dominate in these people's lives? "Our consciousness, however - as written by Maciej Kuczyński - is capable of transform these patterns and create the new ones" (Kuczyński, 1997, p. 13).

For man individuals who build their awareness of chances and opportunities provided by the last stage of life, time becomes their special ally. Its specific nature means that older people - seeing the inevitability of the coming end - still strive for self-development as they recognize that such activity is the best way to neutralize the whole range of deficiencies in this phase of their existence. First of all, they must deal with the fact of them retiring and the subsequent change of social roles and modification of the character of their interpersonal relations. In this situation time gains particular importance because it allows seniors to complete the tasks that they did not previously have time to do. Moreover, late adulthood entails the range of specific difficulties and challenges that require the application of adjustment mechanisms, "especially, flexibility and adaptability" (Turner, \& Helms, 1999, p. 526). The full awareness of the value of the last stage of life makes these people respect the time they still have at their disposal. Energy released thanks to this attitude allows them to fight with all body deficiencies with a relative success.

The analysis of the human ageing phenomenon from the perspective of the passing time makes us realize that in their last stage of life individuals often try to take stock of their existence. Summing up numerous experiences as well as resulting successes and failures usually ends with the global assessment of one's life. The derivative of the long course of life and evaluation of it is wisdom, understood as "the ability to cope with life, resulting from the life experience, from practical approach to life" [Słownik języka polskiego (Dictionary of the Polish language), 1998, p. 129]. This wisdom can usually be considered as an individual attribute of older adults, as it allows them to overcome many difficult situations. So the perspective of the passing time and 
near end of one's life naturally deepens the auto-biographical reflection; and the significance of the latter - from the point of view of axiology of personal identity - is unquestionable.

A very different attitude towards life is presented by people who are afraid of their old age and view it as the unwanted twist of fate. For them time goes very slowly, as the lack of faith in the causal power of activity makes them slaves of the bad, meaningless old age. For some people time becomes such a burden that they remove it by ending their life with suicide. The stereotype of bad old age, deeply anchored in their consciousness as well as their previously negative socialization, turns their last life stage into an ordeal.

However, we cannot exclude the third approach to time in the late adulthood, which is revealed by people who view their final stage of life as the period of gradual stillness and focus on spiritual development. This is connected with successive resignation from fulfilling certain roles which, by absorbing time and energy, limited their capacity for in depth reflection on the ultimate meaning of life. The spiritual dimension of late adulthood creates the space for self-reflection, improves one's self-evaluation skills as well as allowing development of the skills of creating emotional distance towards the trivia of everyday life (Harwas-Napierała, \& Trempała, 2000, p. 10). It is worth noticing that Maria Straś-Romanowska treats spiritual development as the fourth dimension of psychical life. This dimension involves "individuals discovering - through their subjective experience - the non-material, metaphysical reality that is the source of the absolute value and the supreme sense of life" (Straś- Romanowska, 2003, p. 47).

\section{SUMMARY}

To summarize, we need to point out that temporal perspective in each of the three stages of adulthood undergoes far-reaching diversification. Assuming that adults have relatively regular contact with knowledge and constantly take advantage of various forms of transferring this knowledge, we can state that the value of time increases with years passing by. Apart from the dark scenario of late adulthood, in all other cases the price of time, as non-renewable good, constantly grows.

It seems that as years go by, we subjectively feel that time accelerates. While searching for the reason for this state of affairs, we can conclude that this acceleration is fostered by:

- the increasing number of devices and civilizational and cultural attractions;

- the growing number and quality of life tasks;

- the increasing level of understanding the world and the mechanisms that rule over it. 
The above listed factors lead us into the realization of the enormity of tasks which could potentially construct our life roles. Thus, despite our deteriorating condition, we try to fulfill some of them at least partially, shortening this way our subjective perception of free time, which in turn accelerates the rate time passes by.

Even though "the ticking of the biological clock", especially in late adulthood, is "much more profound" (as noticed by H. Bee), due to their reflexive consciousness elderly people are not only able to sustain their "state of possession" in the psycho-social and intellectual sphere but also undertake educational activities that contribute to their development (Semków, 2012, p. 145).

\section{REFERENCES}

[1] Avanzini, G. (1993). Efekty kształcenia a dorosłość człowieka [Learning Outcomes and Human Adulthood]. In: A. Trzuskowski (Ed.), Edukacja dorostych w sytuacji przemian na tle porównawczym [Adult Education in the Situation of Transformation - a Comparative Perspective] (pp. 45-49). Łódź: StarCo.

[2] Bee, H. (2004). Psychologia rozwoju człowieka [Lifespan Development]. Poznań: Zysk i Ska.

[3] Chopra, D. (1995). Życie bez starości. Młode ciało ponadczasowy umyst [Ageless Body, Timeless Mind. The Quantum Alterantive to Growing Old]. Warszawa: Książka i Wiedza.

[4] Harwas-Napierała, B., Trempała, J. (Eds.). Psychologia rozwoju człowieka. Rozwój funkcji psychicznych (tom 3) [Developmental Psychology. Development of Psychical Functions (vol 3)]. Warszawa: PWN.

[5] Jaślar, J. (2015). Etyka i czas. Wariacje aretologiczne [Ethics and Time. Aretological Variations]. Kraków: Księgarnia Akademicka.

[6] Kuczyński, M. (1997). Życie jest myśla [Life is a Thought]. Warszawa: Wydawnictwo ALFA.

[7] Oleś, P. K. (2000). Psychologia przełomu połowy życia [Psychology of Midlife Breakthrough]. Lublin: Towarzystwo Naukowe KUL.

[8] Semków, J. (2012). Szanse i możliwości rozwoju człowieka w okresie średniej i późnej dorosłości [Chances and Opportunities for Development of Man During Middle and Late Adulthood]. GentesENationes. Studia z Zakresu Spraw Międzynarodowych, 2, pp. 143-149.

[9] Szymczak, M. (1998), Stownik jezyka polskiego [Dictionary of the Polish language]. Warszawa: PWN.

[10] Straś-Romanowska, M. (2003). Wspomaganie ludzkiego rozwoju w świetle założeń dotyczących jego ukierunkowania [Supporting Development in the Light of Assumptions for Directing Human Development]. In: B. Kaja (Ed.), Wspomaganie rozwoju. Psychostymulacja, Psychokorekcja (tom 5) [Develoment Support. Psychostimulation, Psychocorrection, (vol 5)] (pp. 40-54). Bydgoszcz: Wydawnictwo Akademii im. K. Wielkiego.

[11] Turner, J. S., Helms, D. B. (1999). Rozwój człowieka [Lifespan development].Warszawa: WSiP.

[12] Zimbardo, F., Boyd, J. (2009). Paradoks czasu [Time Matters].Warszawa: PWN. 